\title{
Güneydoğu Anadolu Osmanlı Dönemi Camilerinde Çini Süsleme (Şanlıurfa ve Gaziantep Örnekleri)
}

\section{Tile Decoration in the Ottoman Period Mosques at Southeast Anatolian (Şanlıurfa and Gaziantep Examples)}

\author{
Turgay Polat \\ Dr. Öğr. Üyesi Adıyaman Üniversitesi, Fen Edebiyat Fakültesi, Sanat Tarihi Bölümü \\ email: tpolat@adiyaman.edu.tr DORCID ID: https://orcid.org/0000-0003-0883-9153
}

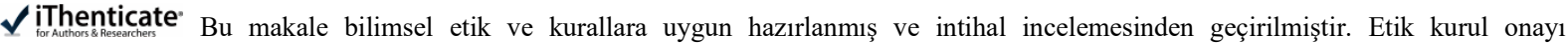
gerektirmemektedir.
\end{abstract}

Atıf (APA 7)/To cite this article

Polat, T. (2021). Güneydoğu Anadolu Osmanlı dönemi camilerinde çini süsleme (Şanlıurfa ve Gaziantep örnekleri). Atatürk Üniversitesi Güzel Sanatlar Enstitüsü Dergisi, 27(47), 532-547. https://doi.org/10.35247/ataunigsed.971803

Makale Gönderim Tarihi/Received: 15/07/2021

Makale Kabul Tarihi/Accepted: 05/10/2021

Makale Yayın Tarihi/Published: 28/10/202

Review Article / Derleme Makale

Öz

Osmanlı Dönemi çini sanatı hakkında yapılan çok sayıdaki araştırma sayesinde bu dönemin çini süslemeleri hakkında oldukça detaylı bilgilere sahibiz. Günümüzde yapılan araştırmalar ile bu bilgiler her geçen gün daha da artmaktadır. Osmanlı döneminde, özellikle 16. yüzyılda İznik üretimi çiniler, başta başkent olmak üzere İmparatorluğun çeșitli bölgelerinde inșa edilen yapıları süslemekte kullanılan ana bezeme malzemelerinden birisi olmustur. İznik'in yanında Kütahya, Tekfur Sarayı ve Diyarbakır gibi İstanbul ve Anadolu'nun farklı bölgelerinde çini üretildiği ve mimari süslemede kullanıldıkları da bilinmektedir. Çalışmamız kapsamında değerlendirdiğimiz Güneydoğu Anadolu Bölgesi'nde yer alan Şanlıurfa ve Gaziantep sehirlerinin coğrafi konumları göz önüne alındığında, İznik'ten bu bölgeye çini getirilmesi zor ve zahmetli olacağ için bu şehirlere daha yakın olan Diyarbakır ve Suriye'den muhtemelen stok (depo) çinilerin getirildiği ve süslemede kullanıldıkları anlaşılmaktadır. Özellikle Diyarbakır, Şam ve Halep gibi bölgelerde inşa edilen yapıların yerel atölyelerde üretildikleri düşünülen çinileri ile Şanlıurfa ve Gaziantep şehirlerindeki yapıları süsleyen karolar halindeki birbirlerinden farklı çinilerin çok yakın benzerlikler taşıması bu fikri güçlendiren bir durumdur. Şanlıurfa ve Gaziantep şehirlerindeki çinilerin benzer örnekler ile birlikte değerlendirilmesi, Osmanlı mimarisinde İznik dıșındaki merkezlere ait çinilerle süslü yapıların tanıtılması ve Diyarbakır ile Suriye'deki üretim merkezlerinin 16.-17. yüzyıllarda bölgedeki yapıları süsleyen çinileri ürettiklerini göstermesi açısından önemli olacaktır.

Anahtar kelimeler: Çini, Mimari, Süsleme, Osmanlı, Cami

\begin{abstract}
Thanks to the numerous studies on the Ottoman period tile art, we have very detailed information about the tile decorations of this period. With today's research, this information is increasing day by day. Especially in the 16th century, tiles produced in Iznik became one of the main decoration materials used to decorate the structures built in various regions of the Empire, especially in the capital. It is also known that tiles were produced in Istanbul and Anatolia, such as Kütahya, Tekfur Palace, and Diyarbakır, as well as Iznik, and they were used in architectural decoration. Considering the geographical locations of the cities of Şanliurfa and Gaziantep, which are located in the Southeast Anatolian Region, which we evaluated within the scope of our study, it would be difficult and troublesome to bring tiles from Iznik to this region. Therefore, it is understood that probably stock (warehouse) tiles were brought to these two cities from Diyarbakır and Syria, which are closer to Sanliurfa and Gaziantep, and were used for decoration. The fact that the tiles of the buildings built in regions such as Diyarbakır, Damascus, and Aleppo, which are thought to have been produced in local workshops, and the different tiles that adorn the buildings in Şanlıurfa and Gaziantep, bear very close similarities, which strengthens this idea. Evaluating the tiles in Şanlıurfa and Gaziantep together with similar examples, introducing the structures decorated with tiles from the tile centers outside of İznik in Ottoman architecture, and the 16 th-17th century tile centers in Diyarbakır and Syria. It will be important in terms of showing that they produced the tiles adorning the structures in the region in the centuries.
\end{abstract}

Keywords: Tile, Architecture, Ornament, Ottoman, Mosque

\section{Giriş}

Güneydoğu Anadolu Bölgesi'nin gelişmiş iki şehri olan Şanlıurfa ve Gaziantep, bünyelerinde barındırdıkları farklı dönemlere ve kültürlere ait taşınmaz kültür varlıkları ile dikkat çekmektedirler. VII. yüzyılda İslam Devleti tarafından fethedilinceye kadar birçok farklı medeniyete ev sahipliği yapmış olan Şanlıurfa bu dönemden sonra da sürekli olarak Bizans, Selçuklu, Haçlılar ve Ermeniler gibi farklı devletler arasında el değiştirmiş, Alâaddin Keykubat Döneminde Anadolu Selçuklu Devleti'nin himayesine girmiş, XV. yüzyılda Akkoyunlu himayesinde kalmış (Paydaş, 2017, s. 217-225; Turan, 2010, s. 336-341) ve nihayet 1517 yılında Osmanlı tarafından fethedilmiştir. Osmanlı Devleti tarafından fethedilene kadar oldukça köklü bir geçmişe sahip olan Şanlıurfa'da Roma, Bizans, Zengi, Eyyubi, Akkoyunlu ve Osmanlı dönemlerine ait çok sayıda eserle karşılaşmak mümkündür. Osmanlı dönemi eserleri arasında yer alan Dabakhane ve Yusuf Paşa camileri ile Artuklu döneminden kalma Siverek Ulu Cami süslemelerinde çinilerin kullanıldığı yapılardır. Gaziantep ve Kilis gibi yakınında yer alan şehirlerde bulunan camilerde olduğu gibi Şanlıurfa camilerinde de çini genellikle minarelerde karşımıza çıkmaktadır. Farklı tekniklerde ve kompozisyonlarda olan bu çinilerin tarihlendirilmesi ve benzer örneklerle değerlendirilmesi özellikle Güneydoğu Anadolu bölgesinde Osmanlı dönemi çini sanatının gelişimi hakkında yeni 
bilgiler edinmemize yardımcı olacaktır. Çalışmamız kapsamında çini süslemeli yapıların incelendiği bir diğer şehir Gaziantep’tir. Güneydoğu Anadolu Bölgesi ile Akdeniz Bölgesi'nin kesişim noktasında yer alan Gaziantep, topraklarından İpek Yolu'nun geçmesi sebebiyle daima gözde ve zengin bir yerleşim alanı olmuştur (Eroğlu Bilgin, 2017, s. 15). M.Ö. 1800-1200 yılları arasında Hititlerin önemli merkezi olan şehir, Hititlerden sonra Medler, Persler, Seleukoslar, ve Kommagene krallıklarının himayesinde kalmış, daha sonra Roma ve Bizans egemenliğine girmiştir (Özdeğer, 1996, s. 466). VII. yüzyılın ilk yarısında İyaz Bin Ganem komutasındaki İslam orduları tarafından fethedilen bölge, 782 yılına kadar sürekli olarak Araplar ve Bizanslılar arasında el değiştirmiştir (Altın, 2015, s.18). 11. yüzyıldan itibaren Türklerin bölgeyi fethetmeye başlamasıyla beraber bölgede kurulan Haçlı Kontluğu ile birlikte Antep ve bölgesi Edessa Kontuluğu’na bağlanmıştır (Özdeğer, 1996, s. 466). 11. yüzyılda Halep Selçuklularına bağlı olan bölge, daha sonra Memlukler ve Dulkadirli Beyliği arasında egemenlik mücadelelerine sahne olmuştur. 1516 tarihinde Yavuz Sultan Selim'in Mısır üzerine yaptığı sefer sırasında Memlüklerin Antep valisinin Osmanlı tarafına geçmesi ile şehir savaşmadan fethedilmiştir (Özdeğer, 1996, s. 467; Altın, 2015, s. 25; Eroğlu Bilgin, 2017, s. 16). İslam orduları tarafından fethedildikten sonra bölgede özellikle Selçuklular, Memlükler ve Dulkadirli dönemlerinde çok sayıda eser inşa edilse de bunların büyük çoğunluğu günümüze ulaşmamıştır. Şehirde ilk esaslı inşa faaliyetlerinin Eyyubiler döneminde başladığı bildirilmektedir (Çam, 1996, s. 470). Sonrasında Memluk ve Dulkadirli Beyliği dönemlerinde de imar faaliyetlerinin bulunduğu şehirde Osmanlı Döneminden kalma çok sayıda eser ile karşılaşılmaktadır. Özellikle iki renkli taş işçiliği ile dikkat çeken Gaziantep camilerinde çini süslemeler ile karşılaşılan Ağa Cami, Ali Nacar Cami, Bostancı Cami ve Handan Bey Cami çalışmamız kapsamında değerlendirilmiştir. Gaziantep ve Şanlıurfa'da yer alan camilerdeki çini süsleme detaylı olarak teknik, form, renk ve kompozisyon özellikleri itibariyle incelendikten sonra üretim yerleri hakkında çıkarımlarda bulunulmaya çalışılmıştır. Böylelikle Osmanlı Devleti'nin sınırları içindeki Anadolu'nun güneydoğusunda yer alan bu iki kent özelinde, İmparatorluğun farklı bölgelerinde başkent üslubundan bağımsız olarak çini süslemenin uygulanışı hakkında yeni fikirler ve örnekler sunulmuş olacaktır.

\section{Yöntem}

Araştırma betimsel araştırma modeline uygun olarak yürütülmüştür. Araştırma kapsamında Şanlıurfa ve Gaziantep’te yer alan Osmanlı dönemi yapıları arasında çini süslemeye sahip örnekler tespit edilmiş, gözlem, araştırma ve karşılaştırma teknikleri kullanılarak bu çinilerin üretim yerleri belirlenmiş ve Osmanlı Dönemi çini sanatı içindeki yerleri hakkında çıkarımlar yapılmıştır.

\section{Bulgular ve Yorum}

\section{1. Şanlıurfa Camilerinde Çini Süsleme}

Şanlıurfa'da çini bezemeye sahip en erken tarihli yapı Siverek Ulu Cami' dir. Siverek ilçe merkezi Cami-i Kebir Mahallesi'nde yer alan yapının son cemaat yerinde bulunan kitabeye göre burası 1888 yılında yapılmıştır (Karakaş, 2012, s. 449; K1lavuz, 2005, s. 382). Ayrıca minarenin doğu cephesinde iki, batı cephesinde de bir tane olmak üzere üç kitabe daha yer almaktadır. Batı cephesinde, minare kapısının üstündeki kitabede minarenin 1574 yılında tamir edildiği yazmaktadır (Karakaş, 2012, s. 450). Doğu cephesinde yer alan kitabelerden altta olanda Firavus oğlu Karaslan oğlu Muhammed oğlu Hamdullah ismi geçmektedir ki; bu isimden hareketle cami ve minarenin Artuklular tarafindan XII. yüzyıl sonu-XIII. yüzyıl başında inşa edildiği, 1574 yılında kapsamlı bir onarım geçirdiği veya yeniden inşa edildiği düşünülmektedir (Kılavuz, 2005, s. 383; Kürkçüoğlu, 2013, s. 199). Çok kubbeli ulu camiler plan şemasına sahip olan yapı, dikine dikdörtgen planlı olup, merkezde dört ayak tarafından üç sahına ayrılmış olan harim kısmının üzeri dokuz eş büyüklükte kubbe ile örtülmüştür (Görsel 1). Caminin kuzeydoğu köşesinde yükselen çini süslemeye sahip minare form itibariyle kare kaideli, silindirik gövdeli, tek şerefelidir. Minaredeki çini süslemeler iki bölümlü olarak ele alınan pabuç kısmında yer almaktadır. Pabuç kısmının ilk bölümü aslında kare şekilli olup dört köşeden prizmatik üçgenlerle şekillendirilmiştir. Köşelerden üçgenlerle şekillendirilen pabucun güney yönünde minarenin kapısı yer almakta olup, doğu, batı ve kuzey yönlerinde orta bölüme denk gelecek şekilde kabartma şekilli madalyonlar işlenmiştir. Bu madalyonlardan doğu cephesinde yer alan örneğin üzerinde yatay dikdörtgen formda yeşil tek renk sırlı çini görülmektedir. Bu cephede yer alan madalyonun iki kenarında, köşelerdeki üçgenlerin başlangıç noktalarında altıgen formda, biri tamamen dökülmüş, diğeri kalan parçalarından kobalt mavisi (lacivert) tek renk sırlı çini olduğu anlaşılan iki karo yer almaktadır. Minare pabucunun ikinci kısmı çini süsleme açısından daha zengindir. Onikigen formda olan bu kısımda dört ana cephede vazodan çıkan çiçeklerin yer aldığı kabartma bir süsleme yer alır. Bu kabartma süslemelerin üstlerinde pabucun birinci bölümünde olduğu gibi yatay dikdörtgen formda, yeşil tek renk sırlı çiniler yer almakla beraber doğu cephedeki çini dökülmüştür. Pabucun ara yönlerinde düzensiz olmakla beraber genelde bir yüz atlamalı olarak yerleştirilmiş altıgen formlu çini panolardan üç tanesi günümüze ulaşmıştır. Bunlardan iki tanesi kobalt mavisi tek renk sırlı çini olmakla beraber kuzeybatı yönde şeffaf renksiz sıraltına mavi-beyaz süslemeli, altıgen formlu çini yer almaktadır. Çininin merkezinde yer alan gül motifi dıştan kolları firuze dolgulu altı kollu yıldız içine alınmıştır ve kenarlarda kalan kısımlarda da yine yarım şekilli gül motifleri görülmektedir (Görsel 2). 


\section{Görsel 1}

Siverek Ulu Cami Genel Görünüş

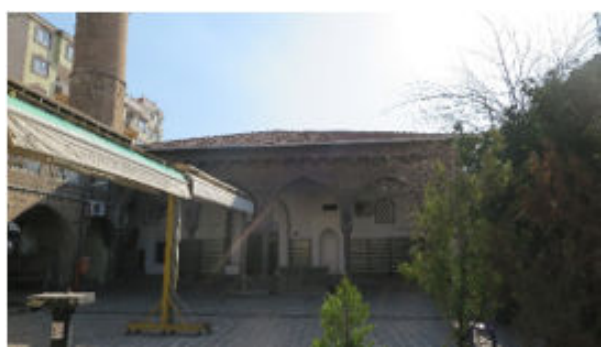

(Polat, 2021)

\section{Görsel 2}

Siverek Ulu Cami Minaresindeki Çiniler

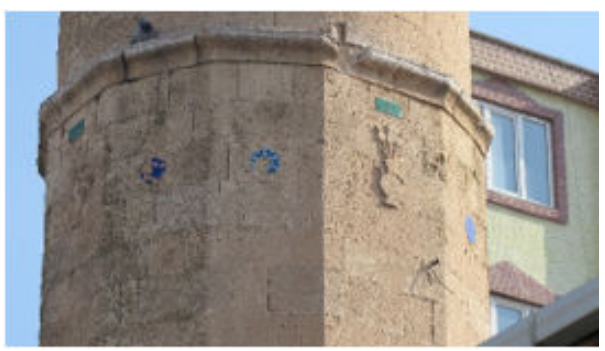

(Polat, 2021)

Şanlıurfa camileri arasında çini bezemeye sahip ikinci örnek, şehir merkezinde, Pınarbaşı Mahallesi 1402. Sokak'ta yer alan Dabakhane Cami'dir. Yapının üzerinde inşa ve onarım süreçleri hakkında detaylı bilgiler veren yedi adet kitabesi bulunmaktadır. Kitabelerden ilki yapının batı kapısı üzerindedir ve bani ismi geçmemekle beraber 1568 yılında II. Selim zamanında yaptırıldığını bildirmektedir. Güney kapısı üzerindeki kitabede 1759 tarihinde kapının Muhammed Bihsevi Ağa tarafından tamir edildiği yazmaktadır. Caminin güney cephesinde yer alan bir diğer kitabeden ise I. Ahmet döneminde (1603-1617) onarım geçirdiği anlaşılmaktadır. Dabakhane Camii'nin son cemaat yeri cephesinde yer alan altlı üstlü yerleştirilmiş iki kitabede 1887 yılında tamir edildiği geçmektedir. Minare kaidesinde bulunan diğer kitabe tarihsiz olmakla beraber Hüseyin Namdar oğlu Seyyid Muhammed tarafından tamir edildiğini göstermektedir. Minarede ayrıca şerefe kapısının üzerinde "Maşallah sene 1248" yazmaktadır ve bu kitabeden de petek ve külah kısımlarının 1832 yılında onarıldığı anlaşılmaktadır (Kılavuz, 2005, s. 314). Avlunun doğu tarafındaki türbede Behram Paşa'nın isminin geçtiği son kitabe ise 1562 tarihini vermektedir (Karakaş, 2012, s. 70-74). Yapının inşa kitabesinin tarihinden daha eski olan tahrirlerde isminin olması inşa sürecinin daha erken tarihlere indiğini düşündürmektedir. 1523 ve 1539 yıllarındaki tahrirde "Evkaf-1 Mescid-i Debbağhane" olarak geçen ismin 1566 yılındaki tahrirde ise "Evkaf-ı Cami-i Debbağhane" olarak geçtiği görülmektedir (Çal, 1993, s. 55-56). Bu da yapının 1523 yılından daha önce mescid olarak inşa edildiğini, ancak zamanla tahrip olması sebebiyle, 1566 yılında camiye çevrilerek 1568 yılında tamamlanacak şekilde büyütüldüğünü veya yeniden inşa edildiğini akla getirmektedir.

Dabakhane Cami’nin enine dikdörtgen planlı harim kısmının üzeri mihraba paralel yerleştirilmiş, yaklaşık olarak eş büyüklükte üç tane kubbe ile örtülmüştür (Görsel 3). Caminin kuzeyinde çapraz tonozla örtülü, altı gözlü son cemaat yeri vardır. Çalışmamız kapsamında incelediğimiz çiniler Dabakhane Cami’nin minare ve kuzey cephesinde yer almaktadır.

Dabakhane Cami minaresi son cemaat yerinin kuzeybatı köşesinde yer almakta olup, kare kaideli, karma gövdeli, tek şerefeli minareler grubundadır. Minare gövdesi iki adet silme ile üç bölümlü olarak düzenlenmiş, alt bölüm silindirik formda, ikinci ve üçüncü bölümler onikigen formda ele alınmıştır. Minaredeki çini süslemeler şerefe altında, üçüncü bölümün onikigen her yüzünde yer alan kabartma şekilli motiflerin altında ve ikinci bölümde her yüzde bulunan sivri kemerli nişlerin ortalarında yer almaktadır (Görsel 4-5). Minarede görülen bu çinilerden kompozisyon açısından farklılık gösteren iki adet çini, son cemaat yerinin ortasına denk gelen çapraz tonozla örtülü giriş kapısının iki yanında, tonozun başlangıç noktasında, küçük taşların farklı şekilde dizilmesi ile elde edilmiş dikdörtgen şekillerinin iki ucuna yerleştirilmiştir (Görsel 6). Kompozisyon düzeni olarak birbirleri ile aynı olan bu iki çinide, merkezde küçük mine çiçeği altı kollu yıldız içinde verilmiştir. Merkezde yer alan çiçeğin yapraklarından kaynaklanan ve iki yana doğru açılan rumilerin kolları ile daha büyük altı yapraklı bir çiçek oluşturulup, bu çiçeğin yapraklarının içlerinde de küçük çiçeklere yer verilmiştir. Rumilerin aralarındaki boşluklar patlıcan moru renkte dolgulanmış ve yarım çiçeklerle doldurulmuştur. Büyük çiçeğin yaprakları lacivert, yıldız ise turkuaz renktedir. Sıraltı teknikli olan bu çiniler altıgen formdadır ve altıgen şekilli kabartma bir yuva içine 
yerleştirilmişlerdir. Şanlıurfa camileri arasında en yoğun çini süslemeye sahip olan Dabakhane Cami minaresinde yer alan çiniler de altıgen formda olup tümünde aynı kompozisyon uygulanmıştır. Sıraltı teknikli bu çinilerde ilk bakışta kuzey cephede yer alan iki çini ile aynı kompozisyon olduğu sanılsa da minaredeki çinilerin bezemesi farklı kompozisyon ile oluşturulmuştur. Bu çinilerde merkezde yer alan düzensiz bir yıldızın kollarından oluşturulmuş üç adet yine düzensiz ve firuze renkle dolgulu altı kollu yıldız görülmektedir. Yıldızların arasında kalan boşluklar lacivert renkle dolgulu olup buralarda küçük mine çiçekleri yer almaktadır. Köşelerde devam ettiği anlaşılan bezemenin yarım yıldızlar ve çiçeklerle sonlandığı görülmektedir. Şerefe altında güneydoğu yönde yer alan çinilerden biri düşmüş, yerine şeffaf sıraltına çok renk bezemeli bir seramik tabak yerleştirilmiştir. Dabakhane Cami minaresinde yer alan çinilerin tümü merkezlerinden çakılan birer çivi (mıh) ile tutturulmuştur.

\section{Görsel 3}

Dabakhane Cami Avlu ve Son Cemaat Yeri Genel Görünüş

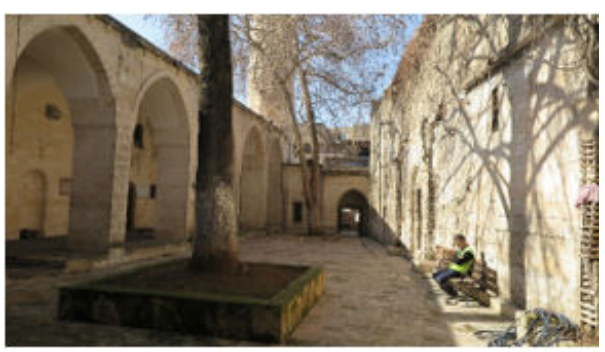

(Polat, 2021)

\section{Görsel 4}

Dabakhane Cami Minare Şerefe Altındaki Çiniler

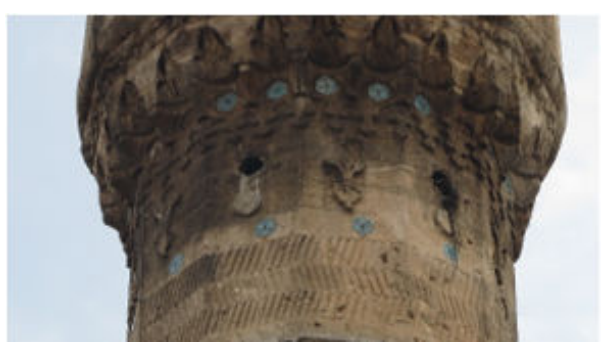

(Polat, 2021)

\section{Görsel 5}

Dabakhane Cami Minaresinin İkinci Bölümündeki Çiniler

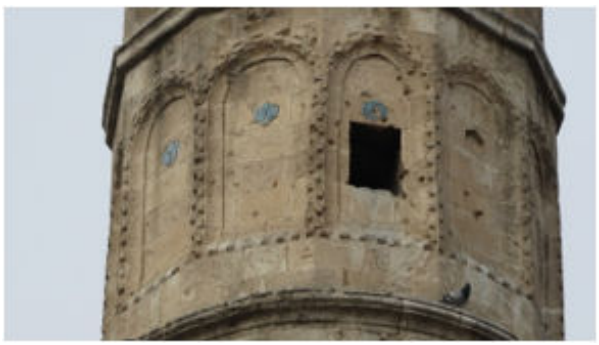

(Polat, 2021)

\section{Görsel 6}

Dabakhane Cami Son Cemaat Yerinde Bulunan İki Çini Karo

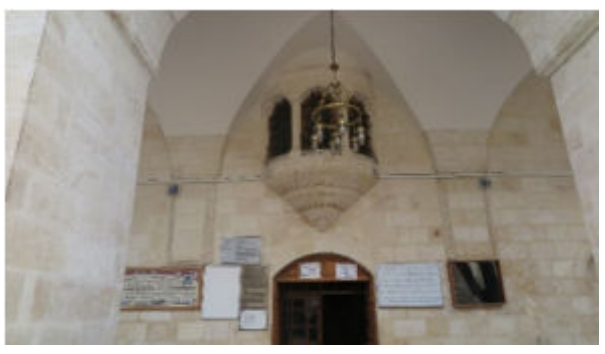

(Polat, 2021) 
Şanlıurfa'da çini bezemeye sahip olduğu anlaşılan ancak bu çinilerin günümüze ulaşmadığı bir diğer örnek Yusuf Paşa Camii'dir. Şanlıurfa şehir merkezinde Bizans Dönemine ait St. Cyriacus Kilisesi'nin üzerine yapıldığ düşünülen (Arslan, 2009, s. 78; Kürkçüoğlu, 1993, s. 41). Yusuf Paşa Camii'nin inşa kitabesi yoktur. Ancak 1710 tarihli vakfiyesinden hareketle yapının banisinin Yusuf Paşa olduğu düşünülmektedir (Memiş, 2019, s. 133). Ayrıca caminin minberi üzerinde 1709 tarihi geçmektedir ve bunun yapının inşa tarihi olduğu ileri sürülmektedir (Karakaş, 2012, s. 149; Kılavuz, 2005, s. 321). Cami merkezli bir külliye olan yapılar topluluğunda medrese hücreleri, tuvaletler, abdesthaneler, hazire, imam odası ve çeşmeler bulunmaktadır. Kareye yakın bir plana sahip olan caminin harim kısmında ortada iki ayak üzerinde oluşturulan altı birimli olup bütün birimlerin üzeri kubbeler ile örtülüdür. Yapının önünde yanları kapalı üç gözlü son cemaat yeri yer almaktadır (Arslan, 2009, s. 73; Kılavuz, 2005, s. 321; Kürkçüoğlu, 2013, s. 70) (Görsel 7).

Yusuf Paşa Cami’nin minaresinde bugün günümüze hiçbir iz kalmasa da çini süslemenin varlığı anlaşılmaktadır. Caminin kuzeybatısında yer alan minare aslında kare kaideli, silindirik gövdeli, tek şerefeli bir minare olmasına rağmen gövde kısmı altta kalın, üste uçları ters palmet şeklinde biçimlendirilmiş silmeler ile üç bölüme ayrılmış, üst ve alt bölümler silindirik, orta bölüm ise sekizgen bir formda ele alınmıştır. Ortadaki sekizgen bölümün en üst kısmında her yüze denk gelecek şekilde dikdörtgen biçimli, derinliği az oyukların çini yuvaları oldukları anlaşılmaktadır. Maalesef bu çinilerden günümüze ulaşan olmamıştır. Minarenin kuzeybatı yönünde bu çini oyuklarının birinin yerine mavi-beyaz bezemeli geç dönem tabağı yerleştirilerek bacini oluşturulmuştur (Görsel 8).

\section{Görsel 7}

Yusuf Paşa Cami Kuzeyden Görünüş

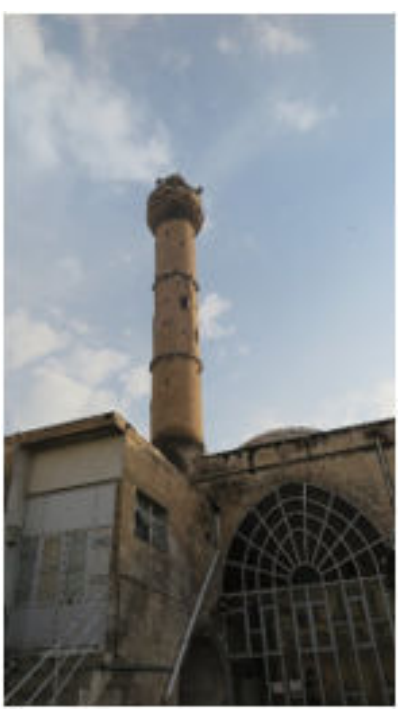

(Polat, 2021)

\section{Görsel 8}

Yusuf Paşa Cami Minare Gövdesindeki Çini Yuvaları ve Bacini

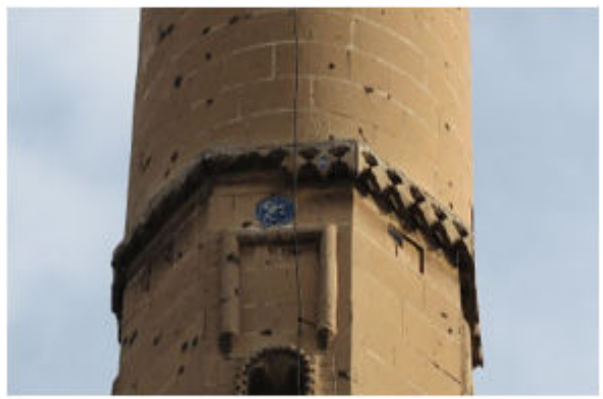

(Polat, 2021)

\subsection{Gaziantep Camilerinde Çini Süsleme}

Gaziantep’te çini süslemelere sahip incelediğimiz ilk yapı Ağa Cami’ dir. Gaziantep şehir merkezi Şahinbey ilçesi Şehitler Caddesi üzerinde yer alan Ağa Cami’nin 1554-1559 yılları arasında inşa edildiği ve 1799 yılında kapsamlı bir onarım geçirerek bugünkü halini aldığ belirtilmektedir (Çam, 2006, s. 171; Eroğlu Bilgin, 2017, s. 51). 
Mihraba paralel iki sahınlı ve mihrap önü kubbeli bir planda olan caminin (Görsel 9) minaresinde çini süsleme yer almaktadır. Yapının önündeki avluda, kuzeydoğuda bağımsız olarak yükselen minare, kare kaideli, karma gövdeli, tek şerefeli bir formdadır. Gövde kalın sarmal şekilli bir silme ile iki bölüme ayrılmış, alt kısım çokgen gövdeli iken üst kısım burmalı olarak inşa edilmiştir. Minarenin şerefe altında burmalı gövde tekrar çokgen forma dönmüş ve bu çokgenin dört ana yönüne dikdörtgen şekilli çinilerin yerleştirildiği kalan izlerden anlaşılmaktadır. Bu çinilerden birçoğu dökülmüş sadece kuzey yönde bir adet çini günümüze ulaşmıştır. Şeffaf sıraltına çok renk bezemeli olan çini panoda merkezde kıvrım dallar üzerinde içi rumilerle dolgulu şemse motifi ile hatayi motifi aynı paralelde verilmiş, bunların çapraz kenar boşlukları küçük, yeşil hançer yaprakları ve penç motifleri ile doldurulmuştur. Panonun kenarlarında görülen yarım şemse motiflerinden devam eden bir kompozisyonun parçası olduğu anlaşılmaktadır (Görsel 10). Şeffaf sıraltına firuze, mavi ve yeşil renklerle bezemelerin oluşturulduğu çini XVI. yüzyılın ikinci yarısı ile XVII. yüzyıla tarihlenen Şam (Suriye) üretimi çinilerle yakından benzerlikler taşımaktadır. Çininin yerleştirilmesinde çivi (mıh) kullanılmamış, alçı veya harç ile tutturulmuştur.

\section{Görsel 9}

Gaziantep Ă̆a Cami Genel Görünüş

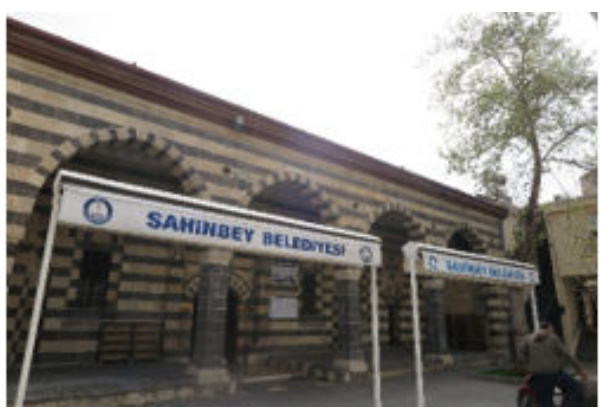

(Polat, 2021)

\section{Görsel 10}

Ă̆a Cami Minaresi Şerefe Altındaki Çini Karo

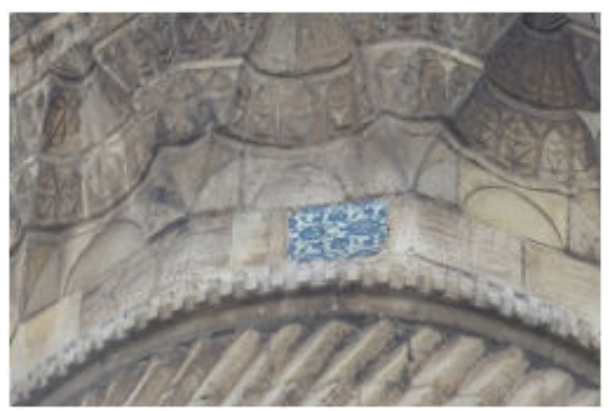

(Polat, 2021)

Gaziantep merkez Şahinbey ilçesinde Kepkep Sokak’ta bulunan Ali Nacar Cami Gaziantep mimarisi içinde önemli yere sahip yapılardan bir tanesidir. 14. yüzyılda inşa edildiği düşünülen yapının daha sonra 1798, 1816, 1820, 1828, 1952 ve 1970 yıllarında geçirdiği onarımlarla günümüze ulaştığı düşünülmektedir (Çam 2006, 27) (Görsel 11). Caminin gülkurusu, siyah ve beyaz taşlarla dama tahtası motifi şeklinde atlamalı bir örgüsü bulunan mihrap nişinin ortasında üç adet çini karo dikkati çekmektedir. Üstte iki, altta bir adet olmak üzere üçlü bir düzenlemede yerleştirilen çinilerden üsttekilerde aynı kompozisyon var iken alt tarafta yer alan çinide hem renk hem de kompozisyon olarak farklı bir çininin yerleştirildiği görülmektedir. Üst tarafta yer alan iki çinide Ağa Cami'de bulunan çini karo ile aynı kompozisyonun uygulandığı görülmektedir. Şeffaf sıraltına çok renk bezemeli olan bu çinilerin merkezinde kıvrım dallar üzerinde içi rumilerle dolgulu şemse ve hatayi motifleri bulunmaktadır. Şemse ve hatayilerin çapraz kenar boşlukları küçük, yeşil hançer yaprakları ve penç motifleri ile doldurulmuştur. Kompozisyon bakımından çok yakın benzerlik taşıyan bu iki panonun detaylarda renk kullanımı açısından farklılıklar gösterdiği anlaşılmaktadır. Soldaki panoda şemse motifinin konturları ile hatayi motiflerinin merkezlerinde firuze renk görülmekteyken sağdaki panoda buralarda soluk kahverengi dikkati çekmektedir. Alt kısımdaki çini panoda ise merkezde küçük bir çiçeğin yapraklarından rumilerle sekiz kollu yıldız oluşturulmuş, yıldız kollarının arasında küçük çiçekler ve lale tohumu şeklindeki motiflere yer verilmiştir. Lacivert dolgulu olan bu kısım en dıştan içleri yeşil renkte dolgulu ve küçük çiçeklerin yer aldığı üçgenler ile daha büyük bir sekiz kollu yıldız içine alınmıştır. Bu bezemenin dört kenarında yarım papatya benzeri çiçekler ile köşelerde yer alan merkez kompozisyonun, çeyrek orandaki kısımları panonun devam eden bir kompozisyonun parçası olduğunu düşündürmektedir. Bazı yayınlarda 16. yüzyılın sonlarına tarihlendiği ve İznik üretimi oldukları belirtilen (Çam 
2006, 30) bu çinilerin (Görsel 12) 16. yüzyılın ikinci yarısı ile 17. yüzyıla tarihlemenin ve Şam/Suriye üretimi olduklarını belirtmenin doğru olacağı kanısındayız. Bu çinilerin dışında mihrabın üst iki köşesinde üzerlerinde "Allah" ve "Besmele" yazan iki adet firuze renkli geç dönem kapları görülmektedir.

\section{Görsel 11}

Ali Nacar Cami Kuzey Cephe Genel Görünüş

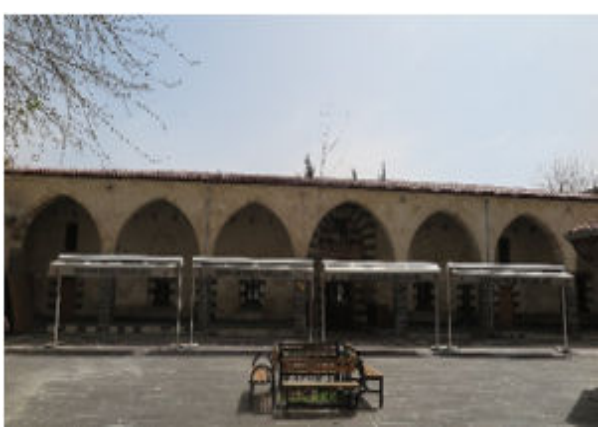

(Polat, 2021)

\section{Görsel 12}

Ali Nacar Cami Mihrap Çinileri

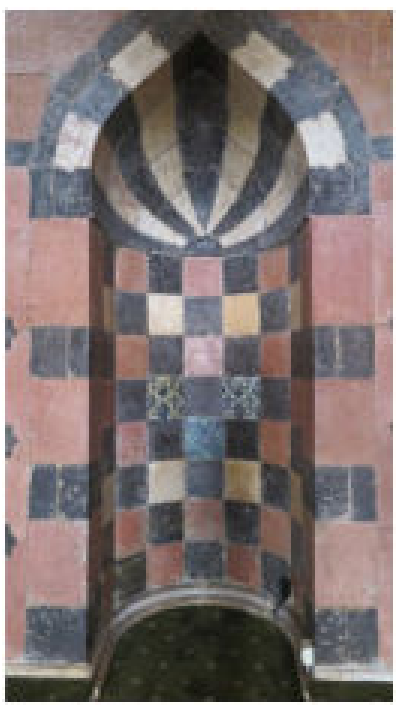

(Polat, 2021)

Hem minaresinde hem de mihrabında çini süslemenin görüldüğ̈̈ Handan Bey Cami Gaziantep şehir merkezi Şahinbey ilçesi, Karagöz Mahallesi'ndedir. Yapının kesin inşa tarihi bilinmese de isminin 1575 tarihli Ayntab vakıf defterinde geçmez iken 1596 yılındaki Şer'i mahkeme sicillerinde geçmesinden dolayı bu iki tarih arasında yaptırılmış olduğu düşünülmektedir (Altın, 2015, s. 180; Çam, 2006, s. 271; Eroğlu Bilgin, 2017, s. 155). Minarenin ise 1797 yılındaki onarım sırasında eklendiği belirtilmektedir (Eroğlu Bilgin, 2017, s. 157). Harimde yer alan kare şekilli iki ayak tarafından mihraba paralel iki sahın oluşturulmuş ve üst örtüde çapraz tonoz kullanılmıştır (Görsel 13). Yapının mihrap nişi Ali Nacar Cami mihrabıyla benzer şekilde sivri kemerli ve üç farklı renkteki taşların atlamalı olarak dizilmesi ile dama tahtası benzeri bir düzenlemededir. Nişin üst kısmında bu taşlardan bir buçuk tanesinin boyutunda dik yerleştirilmiş çini karo dikkati çekmektedir. Ağa ve Ali Nacar camilerinde görülen çiniler ile aynı kompozisyona sahip olan şeffaf sıraltına çok renk bezemeli çinide, kıvrım dallar üzerinde içi rumi dolgulu şemse motifi ile aralarında hatayi, mine çiçekleri ile hançer yaprakları görülmektedir (Görsel 14). Bu karo hançer yapraklarının lacivert renkte olması ile diğer iki örnekten ayrılmaktadır. Handan Bey Cami'nin kuzeybatısında yer alan kare kaideli, çokgen gövdeli, tek şerefeli minaresinin asıl süsleme unsurları şerefe altında görülen yüksek kabartmalı taş süsleme ile hemen bunların üzerinde yer alan bacinilerdir. Ancak minare gövdesinin bitiminde doğu yönde şeffaf renksiz sıraltına çok renk bezemeli çini görülmektedir. Merkezdeki iri hançer yaprağının etrafında bahar açmış dallar şeklindeki süslemenin göze çarptığ çinide, kompozisyonun köşesinde kırmızı renkle dolgulu, kenarları dişli ve içinde lalelerin görüldüğü şemse motifi dikkati çekmektedir (Görsel 15). 


\section{Görsel 13}

Handan Bey Cami Genel Görünüş

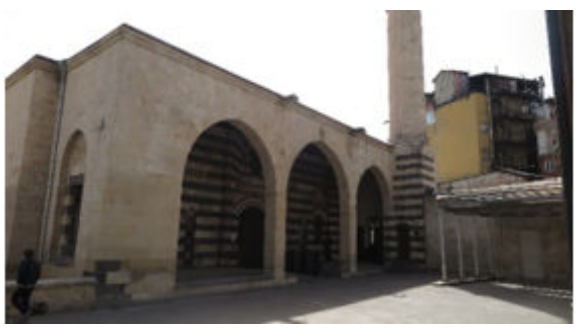

(Polat, 2021)

\section{Görsel 14}

Handan Bey Cami Mihrabı ve Çini Karo

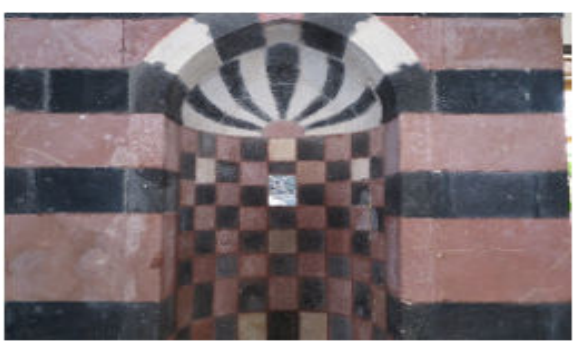

(Polat, 2021)

\section{Görsel 15}

Handan Bey Cami Minaresindeki Çini

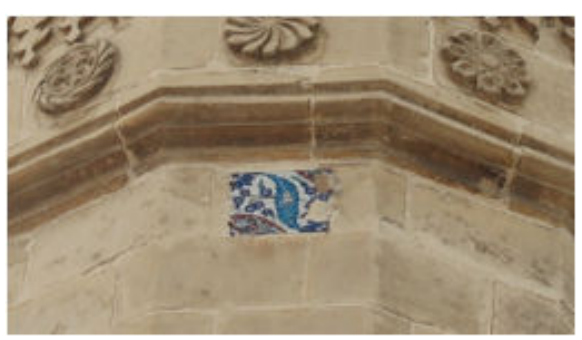

(Polat, 2021)

Gaziantep camileri arasında en yoğun çini süslemeye sahip yapı Bostancı Cami'dir. Gaziantep şehir merkezi Bostancı Sokak'ta yer alan yapının kesin inşa tarihi bilinmemekle beraber 1557 tarihli Ayntab Vakıf Defteri'nde Hasan Bey Mescidi olarak isminin geçtiği bildirilmektedir (Altın, 2015, s. 706). Kitabesine göre 1574 yılında kapsamlı bir onarım geçirerek camiye dönüştürülmüş olan cami, bugünkü halini 1740 yılında geçirdiği büyük onarımla almıştır (Eroğlu Bilgin Güzelbey’den alıntı yaparak bu tarihi 1737 olarak verirken, Çam eserinde bu tarihi 1738-39 olarak vermekte, Altın ise 1740 yılını vermektedir). Kare planlı ve çok birimli olan harim kısmı içten ortada dört kenarlarda on iki ayak tarafından taşınan dokuz çapraz tonozla örtülmüştür (Görsel 16).

Caminin çini süslemeleri kuzey cephede ve minarede karşımıza çıkmaktadır. Kuzey cephesinde minareye çıkışı sağlayan kapı üzerinde şeffaf renksiz sıraltına çok renk bezemeli çini karo yer almaktadır. Bu karoda yan yana dizilmiş, taç yaprakları tomurcuk şekilli iri palmet sırasından bir bölüm görülmektedir. İri palmetlerin içlerinde daha küçük palmetler bulunmakta, bu küçük palmetlerin kenarlarında ise zemin renginde (beyaz) rumiler yer almaktadır (Görsel 17). Yapının kuzeybatısında yer alan kare kaideli, çokgen gövdeli, tek şerefeli minaresinin şerefe altında çapraz ve ters şekilde düzensiz yerleştirilmiş çini karolar dikkati çekmektedir. Onikigen gövdenin bugün sekiz yüzünde kalan çinilerin bazılarında aynı kompozisyon görülmektedir. Minarenin kuzey, güney ve güneydoğu yüzlerinde yer alan çiniler Ağa, Ali Nacar ve Handan Bey camilerinde de karşımıza çıkan çinilerle aynı kompozisyona sahiptir. Şeffaf renksiz sıraltına çok renk bezemeli bu panolarda şemse ve hatayi motifleri kıvrım dallar üzerinde verilmişlerdir (Görsel 18-19). Aralarda yeşil renkte hançer yaprakları ile tamamlanan kompozisyonlarda firuze, lacivert, kahverengi (kırmızı) ve yeşil renklerin uygulandığı anlaşılmaktadır. Minarenin kuzey ve güney yönündeki bu çinilerin kenarlarında kompozisyonun bordur düzenlemesi de görülmektedir. Bu bordürlerde alt ve üstten ikili olarak verilen rumi kollarının arasında küçük palmetlerin yer aldığı görülmektedir. Minare gövdesinin doğu, batı, güney ve kuzeybatıya bakan yüzlerinde form olarak diğer örneklerle benzeşmeyen çiniler yer almaktadır. Ters yerleştirilen ve üst taraflarının dairesel olarak sonlandırıldığı dikey dikdörtgen çini 
karolarda birbirlerinden farklı kompozisyonlar görülmektedir. Bu formdaki çini karolar çok yaygın olarak görülmemekle beraber genellikle kapı ve pencere kenarlarında çerçeve şeklinde kullanıldıkları anlaşılmaktadır (Necipoğlu, 1990, s. 145). Güney yöndeki çinide yeşil dallar üzerinde alt tarafta laleler üst tarafta ise kasımpatı çiçekleri yer almaktadır. Kuzeybatı yöndeki pano tahrip olduğu için kompozisyon tam olarak anlaşılamasa da yine kıvrım dallar üzerinde karanfil motifi seçilebilmektedir. Batı yöndeki panonun köşesinden kaynaklanan dallar üzerinde penç ve lale motifleri ince yapraklar ve dallar ile birlikte verilmiştir. Kuzeybatı yönde bulunan diğer bir çini de ise yapıdaki diğer çinilerle hiç benzeşmeyen kompozisyon yer almaktadır. Belirli bir kompozisyonun parçası olduğu anlaşılan çinide merkezden yanlara açılan rumi kollarından devam eden dallar görülür. Çininin kenarlarında hatayi motiflerinin yarısı görünmektedir ki; buradan kompozisyonun devam ettiği anlaşılmaktadır (Görsel 18).

\section{Görsel 16}

Bostancı Cami Genel Görünüş

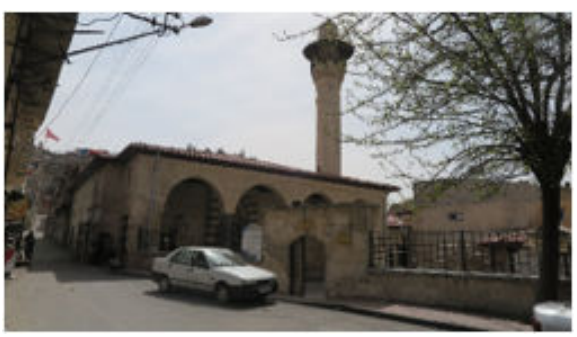

(Polat, 2021)

\section{Görsel 17}

Bostancı Cami Minare Kapısı Üzerindeki Çini

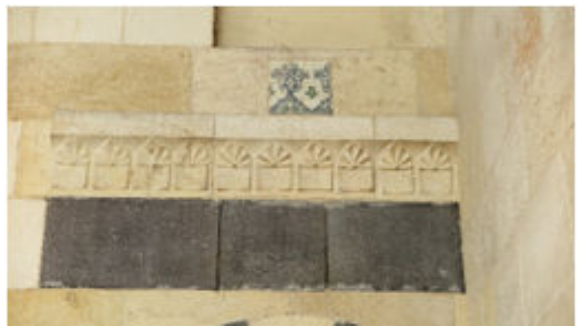

(Polat, 2021)

\section{Görsel 18}

Bostancı Cami Minare Kuzey ve Kuzeybatı Yöndeki Çiniler

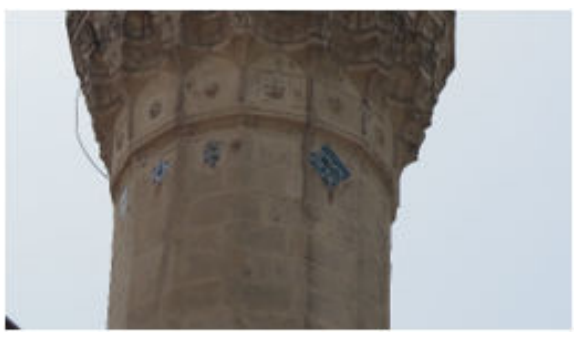

(Polat, 2021)

\section{Görsel 19}

Bostancı Cami Minare Güney ve Güneydoğu Yöndeki Çiniler

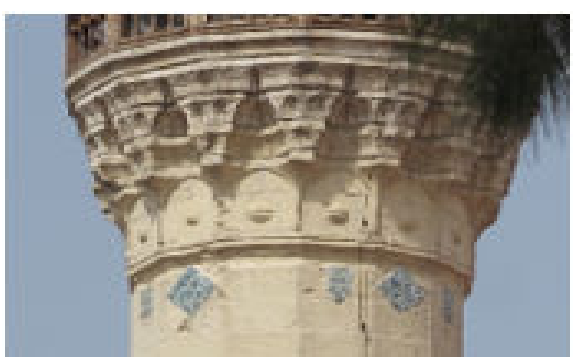

(Polat, 2021) 


\section{Sonuç ve Tartışma}

Güneydoğu Anadolu bölgesinde yer alan yapılar ile ilgili yapılan yayınlarda çini süslemelere çok fazla değinilmediği görülmektedir. Bunda, bölgede yer alan yapılarda çini süslemenin Osmanlı başkentinde yer alan örneklerden farklı şekilde uygulanmasının da etkisi vardır. Özellikle Klasik dönem Osmanlı mimarisi içinde çini süslemenin yapıların güney yönleri ağırlıkta olmak üzere harim duvarlarının tamamını veya bir kısmını kaplamak üzere işlendikleri bilinmektedir. Çalışmamız kapsamında değerlendirdiğimiz yapılarda ise çinilerin genellikle minarelere renk katmak maksadıyla bağımsız karoların çivi yardımıyla çakılması ya da duvara alçı veya harç gibi maddeler yardımıyla tutturulmaları ile elde edilmiştir.

Şanlıurfa ve Gaziantep’te bulunan yapıları süsleyen çinilerin kökenlerine dair bir değerlendirme yapılacak olursa, farklı üretim noktalarından edinilmiş çiniler olduğu anlaşılmaktadır ki; kanaatimizce bu merkezler Diyarbakır ve Şam olmalıdır. Siverek Ulu Cami minaresinde görülen yeşil tek renk sırlı çinilerin minarenin 1888 yılındaki inşası sırasında yerleştirildiklerini düşünmekteyiz. Bu çinilerin detaylı arkeometrik çalışmalar yapılmadan tarihini belirlemek çok zor olsa da hem minarenin inşa tarihi hem de çinilerin form ve sır özellikleri 19. yy. sonu ile 20. yy. başlarına ait yerel üretimler olduklarını düşündürmektedir. Ancak burada minarenin kuzeybatı yönünde yer alan sıraltı teknikli çininin ayrı değerlendirilmesi gerektiği kanısındayız. Teknik ve kompozisyon açısından minaredeki diğer çinilerden ayrılan şeffaf renksiz sıraltına mavi ve lacivert bezemeli bu çini karonun çok yakın benzerlerine Diyarbakır'daki bazı yapılarda rastlamak mümkündür. 16. yüzyılın ilk yarısında geçirdiği onarım sırasında çinilerin eklendiği düşünülen Diyarbakır Safa Cami harim kısmı kuzey ve doğu cephelerinde, batı cephenin kuzey, güney cephenin doğu ucunda aynı teknik, form ve kompozisyona sahip çiniler bulunmaktadır. Ayrıca Diyarbakır Melek Ahmet Paşa Cami doğusundaki mahfile çıkışı sağlayan merdivenlerin yan duvarlarında da çok benzer çiniler yer almaktadır (Yıldırım, 2005, s. 123). Bunun dişında Adana Ulu Cami Türbesi giriş mekânında da benzer çiniler bulunmakla beraber, bu çinilerin çoğunlukla İznik çinilerinin kullanıldığı Adana Ulu Cami Külliyesi'nde görülen mahalli üretim çiniler oldukları düşünülmektedir (Yıldırım 2010, s. 707) (Görsel 20). Siverek Ulu Cami minaresinde yer alan çini karo ile Diyarbakır yapılarında bulunan çinilerin bu kadar çok benzemesi minarede bulunan bu çininin Diyarbakır üretimi olduğunu, stok çini olabileceğini ya da Diyarbakır yapılarından birinden buraya nakledilebileceğini de düşündürmektedir. Zaten Siverek'in Diyarbakır'a coğrafi olarak yakınlığı da bu ihtimali güçlendirmektedir.

\section{Görsel 20}

Siverek Ulu Cami Çinileri ile Diyarbakır örneklerinin Karşılaştırması

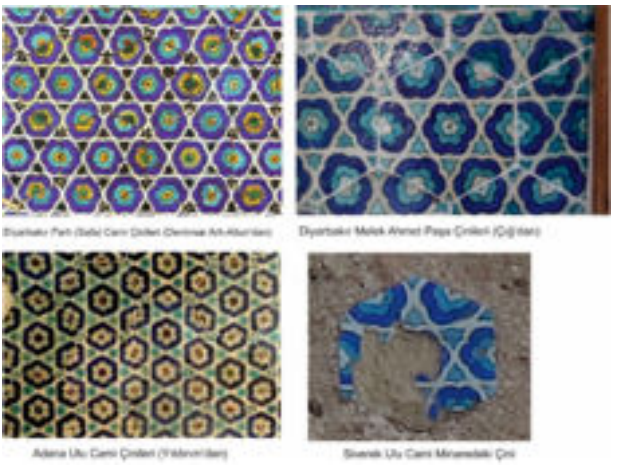

(Çı̆̆g 2014; Demirsar Arlı \& Altun, 2008; Yıldırım, 2010)

Şanlıurfa'ya Diyarbakır'dan getirildiğini düşündüğümüz çiniler bununla sınırlı değildir. Dabakhane Cami kuzey cephesine yerleştirilen iki çini karonun da Diyarbakır'da bulunan yapıları süsleyen çinilerle çok yakın benzerlikler taşıdığı görülmektedir. Teknik, form, kompozisyon ve renk olarak Dabakhane Cami çinilerinin en yakın benzerlerini Diyarbakır Fatih Paşa ve İskender Paşa Cami’ de görmek mümkündür (Çı̆̆g, 2014, s. 12-15; Raby, 1978, s. 453; Yıldırım, 2005, s. 135) (Görsel 21). İznik üretimi 16. yüzyıl çinileri ile benzeşmeyen bu çinilerin Diyarbakır üretimleri oldukları belirtilmektedir (Raby, 1978, s. 453-456; Ünal, 1999, s. 107-109; Yıldırım, 2005 , s. 135). Ayrıca Van Hüsrev Paşa Camisi'nde de benzer teknik, form ve kompozisyonda çinilere rastlanmaktadır (Öztürk, 2021, s. 29-30). Dabakhane Cami minaresindeki bu iki çininin de Diyarbakır üretimi olduklarını düşünmekteyiz. Minaredeki çiniler teknik ve form açısından kuzey cephede bulunan iki karoya çok benzese de kompozisyon açısından çok daha kaba özellikler taşımaktadırlar. Minaredeki çinilerin daha geç tarihli ve yine bölgeye ait yerel üretimler olduklarını düşünmekteyiz. 19. yüzyılın sonu ile 20. yüzyılın ilk çeyreğine ait olması gerektiğini düşündüğümüz bu çinilerin tarihlemesini yaparken referans noktalarımızdan bir tanesi de Yıldız fotoğraf albümleridir. Sultan Abdülhamit tarafından 19. yüzyıl sonu-20. yüzyıl başlarında hazırlatılan bu albümler için Dabakhane Cami'nin de fotoğrafları çekilmiştir. Ancak bu fotoğrafta bugün minarede bulunan çiniler görülmemektedir. Bu durum da çinilerin bu tarihlerden sonra, en erken 19.yüzyıl sonu-20. yüzyılın başlarında minareye eklendiği fikrini güçlendirmektedir. Aynı fotoğraf albümünde Yusuf Paşa Cami fotoğrafi da yer almakta 
ve yapının albümdeki fotoğrafında çinilerin yerleştirildikleri dikdörtgen alanlar görülmekle beraber o dönemde de çinilerin yerlerinde olmadıkları anlaşılmaktadır. Dolayısıyla 1709 tarihli Yusuf Paşa Cami minaresinde 18. yüzyıla ait çinilerin olması gerektiği ve inşasından bir süre sonra bu çinilerin yok olduğu düşünülebilir.

\section{Görsel 21}

Şanlıurfa Dabakhane Cami Çinileri ile Diyarbakır Örneklerinin Karşılaştırması

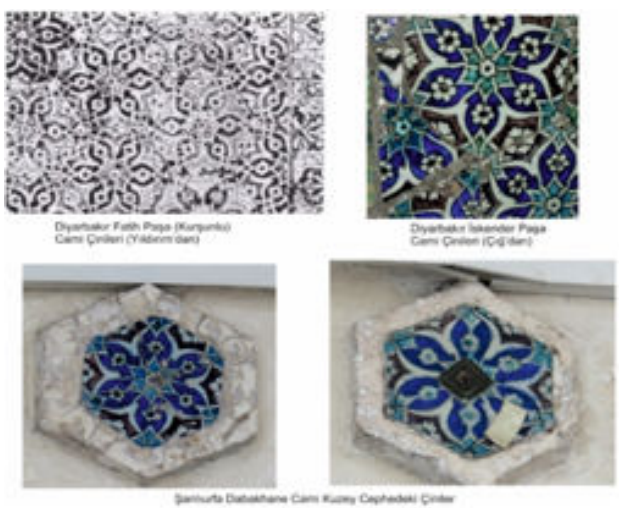

(Çı̆̆ , 2014, Yıldırım 2010)

Gaziantep camilerinde görülen çinilerin benzerlerini ise ağırlıklı olarak Osmanlı dönemi Şam üretimi çinilerde bulmak mümkündür. Ağa Cami minaresinde, Ali Nacar Cami mihrabında, Bostancı Cami minaresinde ve Handan Bey Cami mihrabında yer alan arabesk süsleme içinde hatayi ve șemse motiflerinden oluşan kompozisyonun çok benzerlerine Şam'da üretilmiş Osmanlı dönemi çinilerinde rastlamak mümkündür. Özellikle Şam Süleymaniye Külliyesi'nin medresesi olan Selimiye Medresesi'nin dershane kısmı batı ve güney cephelerinde yer alan çiniler ile yakın benzerlikler taşıdıkları dikkati çekmektedir (Şahin Güçhan ve Kuleli, 2009, s. 96). Ayrıca Londra'da Leighton House olarak bilinen müzenin "Arab Hall” bölümünde yer alan 17. yüzyıl Şam çinileri ile de Gaziantep yapılarındaki çinilerin yakın benzerlikleri görülmektedir (Gibson, 2020, s. 8-13). Benzer teknik ve kompozisyona sahip çinileri Şam Sadeddin Zaviyesi'nde de görmek mümkündür (Carswell, 1978, s. 270-271). Şam'da yer alan Süleymaniye Külliyesi camisinin harim kısmı duvarlarında da 16. yüzyılın ikinci yarısına tarihlenen çinilerde de benzer teknik, form ve renk kullanımlarının olduğu dikkat çekmektedir (Akalın Eryavuz, 2000, s. 46; Bahnassi, 1995, s. 239-240). Bütün bu yapıların dışında Avrupa'da yer alan bazı müzelerde çok yakın benzerlikler taşıyan Şam üretimi 17. yüzyıl çinileri de bulunmaktadır. V\&A Müzesi ve Metropolitan Müzesi’nde görülen 17. yüzyıl Şam üretimi çiniler ile Gaziantep'te adı geçen yapılardaki çinilerin yakın benzerlikleri de Gaziantep yapılarındaki bu çinilerin Şam üretimi oldukları fikrini desteklemektedir (Görsel 22).

\section{Görsel 22}

Gaziantep Camilerindeki Çini Süslemeler ile Suriye Örneklerinin Karşılaştırması

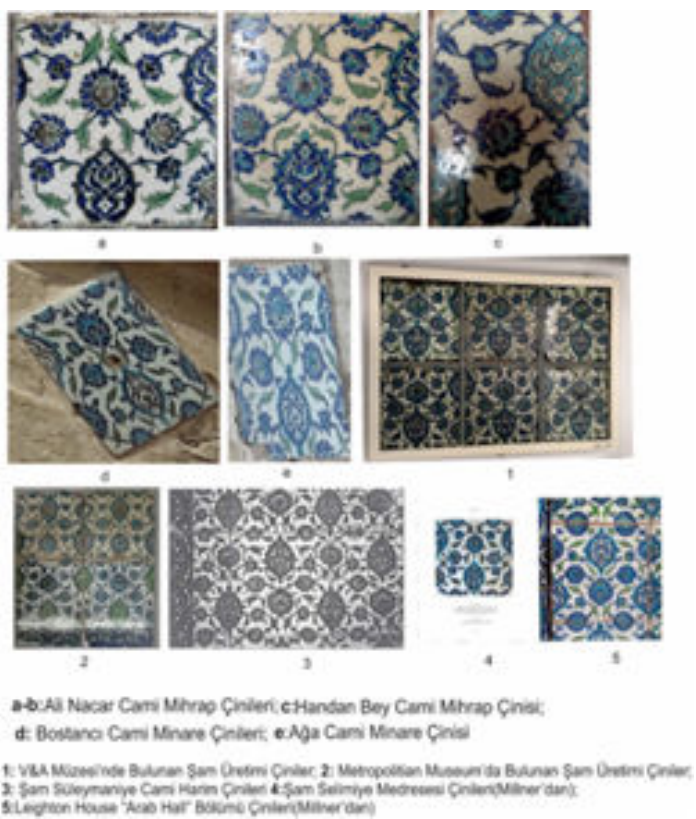

(Metropolitian Museum, t.y.; V\&A Museum, t.y.) 
Gaziantep Bostancı Cami Suriye üretimi olduğunu düşündüğümüz farklı kompozisyona sahip başka çinilere de sahiptir. Minarenin kuzeybatı yönünde bulunan karoda çapraz eksende rumi kollarından kaynaklanan hatayi olduğu anlaşılan motiflerin oluşturulduğu görülmektedir. Çok yakın benzerlerini Kilis Tekke (Canpolat) Cami'nde (Eroğlu Bilgin, 2018, s. 107-124) gördüğümüz bu çinilerin Suriye'de ve Kudüs'te uygulandığı örnekler vardır. Kanuni Sultan Süleyman zamanında Kubbet-üs Sahra'da yapılan onarım sırasında benzer çinilerin eklendiği ve Kubbet-üs Silsile'de benzer çinilerin yer aldığ ifade edilmektedir (Eroğlu Bilgin 2018, 116). Bunun dişında Halep Ulu Cami, Halep Hüsreviye Cami, Halep Canpolat Sarayı (Evi), Adana Ulu Cami'de aynı kompozisyon ve teknikteki çinilere rastlamak mümkündür (Demirsar Arlı ve Altun, 2008, s. 157-161; Eroğlu Bilgin, 2018, s. 119; Tekin, 2008, s. 399; Tekin, 2014, s. 240-241; Yıldırım, 2010, s. 713). Bahsedilen bu yapılarda kullanılan, İznik üretimi olmadıkları anlaşılan ve Gaziantep Bostancı Cami’nde de çok yakın benzeri görülen çinilerin üretim yerlerinin de Suriye (Şam-Halep) olma ihtimali daha yüksek görülmektedir (Görsel 23).

\section{Görsel 23}

Gaziantep Bostancı Cami Minaresinde Yer alan Çini ile Suriye Örneklerinin Karşılaştırması

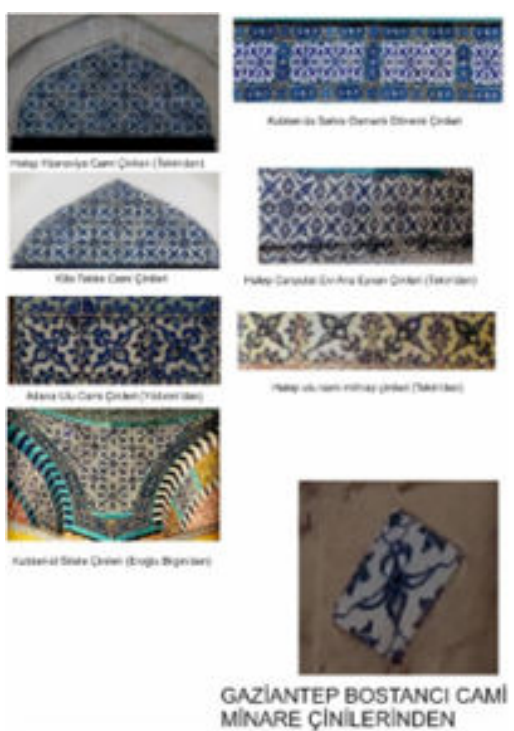

(Polat, 2021)

Bostancı Cami'de son cemaat yerinin kuzeybatısında minareye çıkışı sağlayan kapı üzerinde görülen bir çini karoda iri palmet motiflerinin yan yana verildiği anlaşılan kompozisyondaki çininin de Şam üretimi olduğu düşünülmektedir. Çok yakın benzeri Metropolitan Müzesi’nde sergilenen Şam üretimi 17. yüzyıl çinilerinde, palmetlerin kenarlarında ve aralarında görülen yeşil renkler Şam üretimi Osmanlı dönemi çinilerinde sıklıkla karşımıza çıkmaktadır. Benzer çiniler Adana Ulu Cami bordür çinilerinde de bulunmaktadır (Demirsar Arlı ve Altun, 2008, s. 11). Ayrıca New York The Medina Koleksiyonu'nda da çok yakın benzerliğe sahip çini karo Suriye üretimi olarak belirtilmiştir (Jenkins, 1984, s. 1) (Görsel 24).

\section{Görsel 24}

Gaziantep Bostancı Cami Çinisi ile Benzer Suriye/Yerel Örneklerin Karşılaştırması

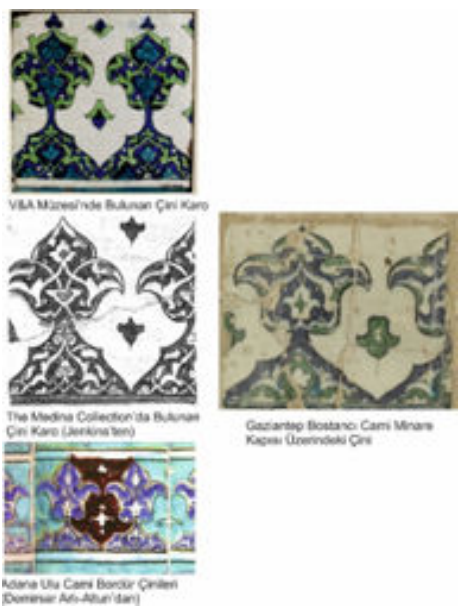

(Demirsar Arlı ve Altun, 2008; Jenkins, 1984; V\&A Museum, t.y.) 
Ali Nacar Cami mihrabında yer alan üçlü düzenlemedeki çini karolardan alt tarafta yer alan karonun da çok yakın benzerlerini Suriye'de görmek mümkündür. Merkezde küçük bir çiçeğin yapraklarından rumilerle sekiz kollu yıldız oluşturulmuş, yıldız kollarının arasında küçük çiçekler ve lale tohumu şeklindeki motiflere yer verilen çini karonun en yakın benzerini Şam Dervişiye Cami'nde ve V\&A Albert Müzesi ile Metropolitan Müzesi'nde bulunan ve 16. yüzyılın ikinci yarısına tarihlenen çinilerde görmek mümkündür (Millner, 2015, s. 272) (Görsel 25).

\section{Görsel 25}

Gaziantep Ali Nacar Cami Mihrap Çinisi ile Suriye Örneklerinin Karşılaştırması

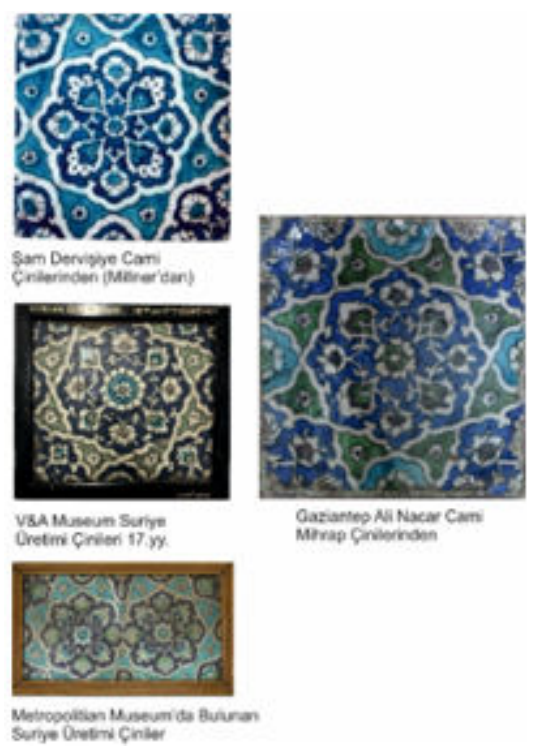

(Metropolitian Museum, t.y.; V\&A Museum, t.y.)

Handan Bey Cami minaresinin kuzey yönünde bulunan çini pano kompozisyon ve renk düzenlemesi açısından diğer örneklerle ayrışmaktadır. İri hançer yaprağı ve bahar açmış dallar kompozisyonun bulunduğu çinide yaprakların içinde ve kenarlarda üç taç yapraklı laleler göze çarpmaktadır. Kompozisyon açısından farklılık gösteren bu karonun çizgiselliği diğer karolara göre daha gelişmiş bir özellik sergilemektedir. Motiflerin sınır çizgileri ve veriliş şekilleri itibariyle İznik çinilerini andıran karonun depo çini olarak veya başka bir yapıdan sökülerek minareye sonradan yerleştirildiğini düşünmekteyiz. Bu çini karonun çok yakın benzerini İstanbul Eyüp Sultan Türbesi'nde görmekteyiz. İlk inşa 1458 tarihli olan türbe, sonraki dönemlerde eklemeler ile günümüze ulaşmış ve türbede16. yüzyıldan 20. yüzyıla varan farklı dönemlere ait çinilerle süslemeler yapılmıştır. Bu çiniler arasında türbenin ziyaret kısmında ve türbeye girişi sağlayan kapının doğu kısmını kaplayan16. yüzyıla tarihlenen çiniler (Demirsar Arlı ve Altun, 2008, s. 268) ile Handan Bey Cami minaresinde görülen çininin çok yakından benzerlik gösterdiği görülmektedir ki; bu benzerlik de Handan Bey Cami minaresindeki çininin 16. yüzyıl İznik çinisi olduğu fikrini akla getirmektedir (Görsel 26).

\section{Görsel 26}

Gaziantep Handan Bey Cami Minare Çinisi ile Eyüp Sultan Türbesi Çinilerinin Karşılaştırması
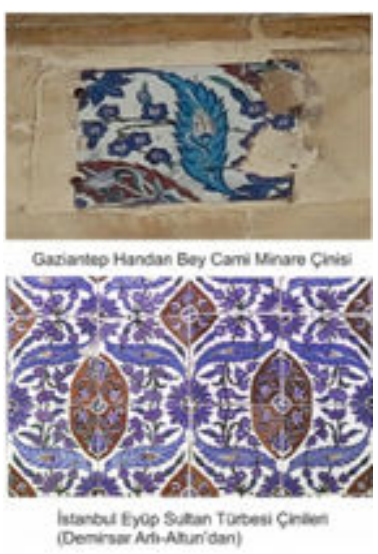

(Demirsar Arlı ve Altun, 2008) 
Şanlıurfa ve Gaziantep gibi Güneydoğu Anadolu Bölgesi'nin iki önemli şehrinde yaptığımız incelemeler sırasında başta minareler olmak üzere yapıların farklı alanlarındaki çini kullanımında belirli bir mesaj kaygısı olmadığını düşünmekteyiz. İnşa edilen yapılara renk katma isteğinin elde bulunan az sayıdaki çini ile gerçekleştirildiğini söylemek daha doğru olacaktır. Şanlıurfa, Gaziantep, Kahramanmaraş, Adıyaman gibi bölgede yer alan şehirlerdeki iki renkli taş işçiliği ve bacini süslemeler de yapılardaki çok renkliliğin diğer simgeleridir. Coğrafi konumları göz önüne alındığında her iki şehrin de Suriye ile yakından bir sanatsal bağlılık içinde bulundukları normal bir olgu olarak görülmelidir. Osmanlı dönemi yapılarının özellikle minareleri incelendiğinde çini uygulamalarının varlığı gözlerden kaçmamaktadır. Ancak İstanbul veya Anadolu dışında bulunan özellikle Selatin camileri değerlendirildiğinde, çinilerin belirli bir düzen içinde, belirli bir kompozisyon dahilinde ve genellikle minarelerde şerefe veya külah altında uygulandıkları görülür. Şanlıurfa ve Gaziantep camilerinin çini süslemelerinin ise herhangi bir düzen içinde olmadığ 1 ve genellikle bir şekilde elde edilen (muhtemelen stok çiniler veya yıkılan yapılardan elde edilen birbirlerinden farklı çinilerin çeşitli yollarla şehre girmesi ile) çinilerin yapıların son cemaat yeri, mihrap veya minare gibi farklı alanlarına düzensiz olarak monte edildikleri anlaşılmaktadır. Şanlıurfa Dabakhane Cami bu düzensizliğin dışında tutulabilir. Çünkü minaresinin farklı alanlarında bulunan çinilerin şerefe altında her yüze ve gövdenin ikinci bölümündeki kemerlerin arasına yerleştirilmesiyle belirli bir düzen içinde olduğu anlaşılmaktadır. Ayrıca minaredeki çok sayıdaki çini karonun tümünde aynı motiflerin bulunması, bu motiflerin belirli bir kompozisyonun parçaları olduğunu göstermektedir. Şanlıurfa camilerindeki çini süslemeyi detaylıca incelediğimiz ve çevre şehirlerdeki örneklerle karşıllaştırdığımız zaman Osmanlı döneminin Anadolu'daki önemli çini merkezlerinden biri olan Diyarbakır'da üretildiği düşünülen çinilerle yakından benzerlikler taşıdıkları anlaşılmaktadır. Bu da bu çinilerin büyük ihtimalle Diyarbakır'dan Şanlıurfa ve Siverek'e getirildiklerini düşündürmektedir. Çiniler arasındaki çok yakından benzerliklerin dışında hem Şanlıurfa'nın hem de Siverek'in Diyarbakır ile yakın mesafede bulunması da bu düşünceyi desteklemektedir. Osmanlı döneminde 16. yüzyılda önemli bir çini üretim merkezi olan Diyarbakır'da üretilen çiniler genel kompozisyon şeması olarak İznik üretimi çinilerle benzerlik taşımakla beraber motiflerin oluşturulmasında daha kaba bir işçilik göze çarpmaktadır. Bunun dışında hamurlarının sarımtırak oluşu ve sırlarında çatlakların oluşması yönünden de İznik çinilerine göre düşük kalitede oldukları anlaşılmaktadır (Raby, 1978, s. 447-448; Yıldırım, 2005, s. 127). Gaziantep yapılarında bulunan çinilerin ise genel olarak Osmanlı dönemi Şam üretimi çinilerle çok yakın benzerlikler taşıdığı görülmektedir. Osmanlı döneminden önce de çininin üretildiği düşünülen Şam'da üretim için daha büyük gelişmelerin yaşanması 1516 yılında Osmanlıların Suriye'yi fethetmesinden sonra başlamıștır. Bu tarihten sonra Şam'da İznik etkili çini üretiminin var olduğu bilinmektedir. Bu anlamda en çok kabul gören görüşün İznik’ten Şam'a usta veya desen şablonlarının gönderildiği yönündedir (Turan Bakır, 2002, s. 575). Çini ve seramik çalışmalarında genellikle "Şam işi”" olarak isimlendirilen bu tipteki çinilerin İznik üretimi çiniler ile yakın benzerliklerinin yanı sıra motiflerindeki kabalık ve renk skalasındaki değişiklikler ile İznik çinilerinden ayrılmaktadır. Gaziantep yapılarında Şam üretimi çinilere rastlanmasının temel sebeplerinden bir tanesi coğrafi yakınlık olabilir. Halep'e yaklaşı $120 \mathrm{~km}$ Şam'a ise yaklaşık $400 \mathrm{~km}$ mesafede bulunan Gaziantep'teki bir yapıyı süslemek için yaklaşık 1000 km uzaklıktaki İznik’ten çini getirmek yerine yakındaki Suriye'den getirmenin daha mantıklı olduğu anlaşılabilir. Ancak getirilen bu çinilerin neredeyse tümü incelenen yapılar için özel olarak üretilmemişlerdir. Dabakhane Cami minaresinde bulunan aynı kompozisyon teknik ve forma sahip çinilerin haricinde Şanlıurfa ve Gaziantep yapılarında çini ya tek karo halinde uygulanmış ya da birbirinden farklı tarzdaki çiniler düzensiz olarak yapıların mihrap ve minare gibi kısımlarına yerleştirilmiştir. Bu özellikleri ile de süslemede kullanılan çinilerin muhtemelen depo (stok) çinilerinden elde edilerek şehirlere getirildiği veya yıkılan başka yapılardaki çinilerin sökülerek bu yapılara yerleştirildiği fikrini akla getirmektedir.

\section{Kaynakça}

Akalın Eryavuz, Ş. (2000). Halep ve Şam'da bulunan Osmanlı dönemi çinileri hakkında gezi notları. Sanat Tarihi Araştırmaları Dergisi, 15, 43-55. http://isamveri.org/pdfsbv/D00109/1999_15/1999_15_ERYAVUZSA. pdf

Altın, A. (2015). Gaziantep Türk-İslam mimarisi (Eyyubiler'den Cumhuriyet'e) (Tez No. 429654) [Doktora Tezi, Atatürk Üniversitesi, Sosyal Bilimler Enstitüsü].Yüksek Öğretim Kurulu Tez Merkezi.

Arslan, M. (2009). Şanlıurfa'da Osmanlı dönemi cami ve mescid mimarisi (Tez No. 240841) [Yüksek Lisans Tezi, Erciyes Üniversitesi, Sosyal Bilimler Enstitüsü]. Yüksek Öğretim Kurulu Tez Merkezi.

Bahnassi, A. (1995). The damascene tielwork in Ottoman buildings. 9. milletlerarası Türk sanatları kongresi bildiriler kitabı (s. 239-250) içinde. T.C. Kültür Bakanlığı Yayınları.

Carswell, J. (1978). Syrian tiles from sinai and damascus. R. Moorey ve P. Parr (Eds.), Archaeology in the levant. essays for Kathleen Kenyon (s. 269-296) içinde. Aris and Phillips.

Çal, H. (1993). Urfa'daki taşınmaz eski eserler hakkında bir ön araştırma. Yeni Harran Çevresi, 1(4), 49-70. 
Çam, N. (1996). Gaziantep-mimari. TDV İslâm ansiklopedisi cilt 13 (s. 469-474) içinde. https://cdn2.islamansiklopedisi. org.tr/dosya/13/C13023283.pdf

Çam, N. (2006). Türk kültür varlıkları envanteri: Gaziantep. Türk Tarih Kurumu Yayınları.

Çı̆̆g, C. (2014). Diyarbakır'daki bazı Osmanlı dönemi çinileri üzerine bir değerlendirme. İstanbul Journal of Social Sciences, 8, 3-22. https://dergipark.org.tr/tr/download/article-file/161939

Demirsar Arlı, V. B., \& Altun, A. (2008). Anadolu toprağının hazinesi: Çini Osmanlı dönemi. Kale Grubu Yayınları.

Eroğlu Bilgin, S. (2017). Gaziantep camilerinde taşs süslemeler. Gece Yayınları.

Eroğlu Bilgin, S. (2018). Kilis Tekke (Canpolat Paşa) Cami ve çini süslemeleri üzerine bir değerlendirme. A. Erkmen ve S. Khadhraoui (Eds.), İksad II. uluslararası sosyal bilimler kongresi bildiri kitabı cilt I (s. 107124) içinde. https://1d89097f-9d02-4a53-bbe8-961b97c7793d.filesusr.com/ugd/614b1f_9e879590cf5 84f4786e161 8edb8362de.pdf

Gibson, M. (2020). 'An oriental kiosk': The building of the 'Arab Hall' at Leighton House in London. Orientations, 51(2), 2-15. https://www.academia.edu/43263546/ An Oriental Kiosk The Building of the Arab Hall at Leighton House in London

Jenkins, M. (1984). Mamluk underglaze-painted pottery: Foundations for future study. Muqarnas, 2, 95-114. https://doi.org/10.2307/1523059

Karakaş, M. (2012). Şanlıurfa il ve ilçelerinde kitabeler. Şanlıurfa İl Kültür ve Turizm Müdürlüğü Yayınları.

Kılavuz, B.N. (2005). Güneydoğu Anadolu Bölgesi Minareleri (Tez No. 160624) [Doktora Tezi, Yüzüncü Y1l Üniversitesi, Sosyal Bilimler Enstitüsü]. Yüksek Öğretim Kurulu Tez Merkezi.

Kürkçüoğlu, C. (1993). Şanlıurfa camileri. Şanlıurfa İli Kültür Eğitim Sanat Araştırma Vakfı Yayınları.

Kürkçüoğlu, C. (2013). Şanlıurfa ili camileri. Şanlıurfa Belediyesi Yayınları.

Memiş, M. (2019). Vakfiyeleri ışı̆̆ında Osmanlı dönemi Urfa camilerinde vakıf hizmetleri. Vakıflar Dergisi, O(51), 131-152. https://dergipark.org.tr/tr/download/article-file/757818

Metropolitian Museum (t.y.). Suriye Şam üretimi çinileri [Fotoğraf]. THEMET. https://www.metmuseum.org/ artcollection/searchField/445000\%20searchfield/

Millner, A. (2015). Damascus tiles: Mamluk and Ottoman architectural ceramics from Syria. Prestel,

Necipoğlu, G. (1990). From international Timurid to Ottoman: A Change of taste in sixteenth-century ceramic tiles. Muqarnas, 7, 136-170. https://doi.org/10.2307/1523126

Özdeğer, H. (1996). Gaziantep. TDV İslâm ansiklopedisi cilt 13 (s. 466-469) içinde. https://cdn2.islamansiklopedisi.org.tr/ dosya/13/C13023282.pdf

Öztürk, Ş. (2021). Van Hüsrev Paşa Külliyesi mimari süsleme ve onarımı. Atatürk Üniversitesi Güzel Sanatlar Enstitüsü Dergisi, 27(46), 23-43. https://doi.org/10.32547/ataunigsed.822195

Paydaş, K. (2017). Memlukluler (1250-1517) ve Ak-Koyunlular (1378-1508) Urfa üzerindeki hakimiyet mücadeleleri. K. Şulul, M. Şeker, \& Ö. Sabuncu (Eds.), Íslam Tarihi ve Medeniyetinde Şanlıurfa Sempozyum Tebliğleri I (s. 217-225) içinde. Şanlıurfa Büyükşehir Belediyesi Kültür Yayınları. https://www.academia.edu/39703221/Meml\%C3\%BBkler_ve_Akkoyunlular\%C4\%B1n_Urfa_\%C3\%9C zerindeki Hakimiyet $\mathrm{M} \% \mathrm{C} 3 \% \mathrm{BC}$ cadeleleri $\% \mathrm{C} 4 \% \mathrm{~B} 0$ slam Tarihi ve Medeniyetinde $\% \mathrm{C} 5 \% 9 \mathrm{Eanl} \% \mathrm{C}$ 4\%B1urfa I \%C5\%9Eanl\%C4\%B1urfa 2016

Polat, T. (2021). Cami ve çini örneklerinden görüntüler [Fotoğraf]. Turgay Polat Kişisel Arşivi.

Raby, J. (1978). Diyarbakir, A rival to Iznik: A sixteenth century tile industry in eastern Anatolia (Istanbuler mitteilungen). Ernst Wasmuth.

Şahin Güçhan, N., \& Kuleli, A. E. (2009). Şam Süleymaniye külliyesi ve koruma sorunları. Vakıflar Genel Müdürlüğ̈̈ Yayınları.

Tekin, K. H. (2008). Halep’teki Osmanl dönemi dini eserleri (Tez No. 231069) [Doktora Tezi, Erciyes Üniversitesi, Sosyal Bilimler Enstitüsü]. Yüksek Öğretim Kurulu Tez Merkezi.

Tekin, K. H. (2014). Halep'te Osmanl izleri (1516-1918): 402 ylllk Osmanlı hakimiyetinde Halep'te cami, tekke, zaviye ve türbeler. Çamlıca Yayınları. 
Turan Bakır, S. (2002). Osmanlı döneminde Şam üretimi çiniler. Türkler ansiklopedisi cilt 12 (s. 573-586) içinde. Yeni Türkiye Yayınları.

Turan, A. N. (2010). Şanlıurfa. TDV İslâm ansiklopedisi cilt 38 (s. 336-341) içinde. https://cdn2.islamansiklopedisi.org. tr/dosya/38/C38023232.pdf

Ünal, S. (1999). Farklı bir çini merkezi Diyarbakır, Antik Dekor Dergisi, 1(50), 104-109.

V\&A Museum (t.y.). 17. yüzyıl Şam çinileri [Fotoğraf]. Collections. https://collections.vam.ac.uk/item.0181300/ tiles-unkown/

Yıldırım, S. (2005). Diyarbakır yapılarındaki Osmanlı dönemi çinilerinin tarihlendirmeleri ve üretim yeri hakkında düşünceler. Erdem Dergisi, 15(43), 119-144. https://dergipark.org.tr/tr/download/article-file/683082

Yıldırım, S. (2010). Adana Ulu cami külliyesi çini süslemeleri. Uluslararası Eskişehir Pişmiş Toprak Sempozyumu Bildirileri (s. 701-716) içinde. Eskişehir Tepebaşı Belediyesi Yayınları. https://www.academia.edu/ 17444153/Adana_Ulu_Camii_K\%C3\%BClliyesi_\%C3\%87ini_S\%C3\%BCslemeleri 